\title{
PROFIL PENYAKIT PENYAKIT JANTUNG BAWAAN DI INSTALASI RAWAT INAP ANAK RSUP DR. M. DJAMIL PADANG PERIODE JANUARI 2013 - DESEMBER 2015
}

\author{
Budi Junio Hermawan ${ }^{1}$, Didik Hariyanto ${ }^{2}$, Dinda Aprilia $^{3}$
}

\begin{abstract}
Abstrak
Penyakit Jantung Bawaan (PJB) menempati peringkat pertama dari berbagai penyakit pada bayi. Tujuan penelitian ini adalah untuk mengetahui profil penyakit jantung bawaan di instalasi rawat inap RSUP Dr. M. Djamil Padang. Penelitian ini merupakan studi deskriptif dengan desain potong lintang yang dilakukan di instalasi rekam medik RSUP Dr. M.Djamil Padang dari Juli 2016 sampai Desember 2016. Populasi dari penelitian ini adalah data rekam medik pasien rawat inap penyakit jantung bawaan di Bagian Anak RSUP Dr. M. Djamil Padang dari Januari 2013 sampai Desember 2015 dengan jumlah 85 pasien. Hasil yang didapat yaitu VSD adalah ialah jenis penyakit jantung bawaan terbanyak $(40,00 \%)$. Sebaran usia terbanyak pada kelompok $>1$ tahun $(50,59 \%)$. Pasien terbanyak dengan jenis kelamin laki-laki $(54,12 \%)$. Status gizi pasien PJB didominasi oleh gizi kurang $(75,30 \%)$. Kelainan yang menyertai pasien terbanyak yaitu kelainan paru $(40,00 \%)$, dengan penyakit terbanyak yaitu bronkopneumonia $(21,18 \%)$. Pasien yang memiliki riwayat keluarga hanya $2,35 \%$. Rerata hemoglobin dan hematokrit pasien PJB sianotik lebih tinggi daripada PJB asianotik. Simpulan studi ini ialah penyakit jantung bawaan banyak terjadi dengan jenis VSD, usia > 1 tahun, jenis kelamin laki-laki, gizi kurang, disertai kelainan paru (bronkopneumonia), jarang yang memiliki riwayat keluarga, dengan rata-rata $\mathrm{Hb}$ dan $\mathrm{Ht}$ lebih tinggi pada PJB sianotik.
\end{abstract}

Kata Kunci : penyakit jantung bawaan, anak, profil

\section{Abstract}

Congenital heart disease is ranked first among the other diseases that attack the baby. The objective of this study was to determine the profile of congenital heart disease in pediatric ward of Dr. M.Djamil Hospital Padang. This study was a descriptive cross-sectional design conducted in medical record instalation of Dr. M.Djamil Hospital Padang from July 2016 until December 2016. The population of the study was patients of congenital heart disease in pediatric ward Dr. M. Djamil Hospital Padang from January 2013 until December 2015 with a total sample of 85 patients. The highest type of congenital heart disease is VSD as much as $40.00 \%$. Distribution of most age groups $>1$ year $(50.59 \%)$. Most patients with male sex (54.12\%). The nutritional status of patients with CHD is dominated by malnutrition $(75.30 \%)$. Most comorbid disorder are lung disorder $(40.00 \%)$, with most disease are bronchopneumonia disease $(21.18 \%)$. Patients who have a family history only $2.35 \%$. From all patients found that the average of hemoglobin and hematocrit, are $13.5 \mathrm{gr} / \mathrm{dL}$ and $42.7 \%$. The conclusion is congenital heart disease occurred on the types of VSD, age > 1 year, male gender, malnutrition, comorbid by abnormalities in the lungs (bronchopneumonia), rarely have a family history, with an average hemoglobin $13.5 \mathrm{gr} / \mathrm{dL}$ and hematocrit $42.7 \%$.

Keywords : congenital heart disease, children, profile

Affiliasi penulis: 1. Prodi Pendidikan Dokter Fakultas Kedokteran Universitas Andalas Padang (FK Unand); 2. Sub Bagian Kardiologi Anak FK Unand; 3 Bagian Penyakit Dalam FK Unand
Korespondensi: Budi Junio Hermawan,

Email: budijunio@yahoo.co.id Telp: 085265020555 


\section{PENDAHULUAN}

Dewasa ini angka kejadian beberapa penyakit non infeksi semakin meningkat, baik di negara maju maupun di negara berkembang. Perubahan gaya hidup dan perubahan tingkat sosial ekonomi membawa perubahan pada pola penyakit. Beberapa penyakit non-infeksi, termasuk penyakit kongenital kini semakin dikenal. Angka kejadian penyakit jantung dan pembuluh darah di Indonesia cenderung meningkat dan dapat menyebabkan kecacatan dan kematian. Salah satu penyakit jantung yang cukup banyak adalah penyakit jantung bawaan ${ }^{1}$. Penyakit jantung bawaan (PJB) merupakan bentuk kelainan jantung yang sudah didapatkan sejak bayi baru lahir ${ }^{2}$.

Penyakit jantung bawaan dibagi dua kelompok, yaitu; penyakit jantung bawaan sianotik dan penyakit jantung bawaan nonsianotik. Penyakit jantung bawaan sianotik ditandai oleh adanya sianosis sentral akibat adanya pirau kanan ke kiri, sebagai contoh tetralogi Fallot, transposisi arteri besar, atresia trikuspid, sedangkan kelompok penyakit jantung bawaan nonsianotik adalah penyakit jantung bawaan dengan kebocoran sekat jantung yang disertai pirau kiri ke kanan di antaranya adalah defek septum ventrikel, defek septum atrium, atau tetap terbukanya pembuluh darah seperti pada duktus arteriosus persisten ${ }^{2}$.

Studi yang dilakukan oleh Hoffman dan Kaplan (1968) mengenai insiden penyakit jantung bawaan menunjukkan insiden yang rendah, yaitu $4-5$ per 1.000 kelahiran hidup. Tetapi hasil pada tahun 1995 menunjukkan bahwa insiden PJB meningkat menjadi $12-14$ per 1.000 kelahiran hidup ${ }^{3}$.

Di Poliklinik Kardiologi Anak RSDK Semarang, pada periode Januari 2007 - Desember 2008 dijumpai 135 pasien baru PJB, penyakit jantung asianotik merupakan yang terbanyak yaitu sebanyak $80,74 \%$, jumlah pasien PJB asianotik pirau kiri ke kanan (defek septum ventrikel, defek septum atrium, defek septum atrioventrikuler, paten duktus arteriosus) sebanyak $68,81 \%{ }^{4}$.

Penelitian Windarini mendapatkan dari 131 orang pasien PJB yang diperiksa pada tahun 20072009 di RSUP H. Adam Malik Medan, 75 orang pasien berjenis kelamin perempuan $(57,3 \%)$, dan 56 orang pasien berjenis kelamin laki-laki (42,7\%). Sebagian besar adalah PJB asianotik (93 orang atau 71\%), dan sisanya adalah jenis sianotik (38 orang atau 29\%). Berdasarkan penelitian ini pasien pada kelompok usia 0-24 bulan merupakan kelompok penderita dengan distribusi usia tertinggi ${ }^{5}$.

Menurut hasil penilitian di RSUP Dr. M. Djamil Padang dari tahun 2008-2011, terjadi 98 kasus PJB dengan jenis PJB non sianotik terbanyak yang didapatkan adalah VSD (35,4\%), ASD (35,4\%), dan PDA (33\%). Sedangkan pada PJB sianotik yang terbanyak adalah ToF (15\%), TGA (8\%), dan SV (4\%). Kasus lain-lain berdasarkan hasil $E C H O$ diantaranya adalah AVSD, SA, TA, dan $P H$ yang menyertai PJB lain ataupun murni sebagai kelainan $\mathrm{PJB}^{6}$.

PJB merupakan penyakit yang berbahaya. Bila tidak terdeteksi secara dini dan tidak ditangani dengan baik, 50\% kematiannya akan terjadi pada bulan pertama kehidupan. Di negara maju hampir semua jenis PJB telah dideteksi dalam masa bayi bahkan pada usia kurang dari 1 bulan, sedangkan di negara berkembang banyak yang baru terdeteksi setelah anak lebih besar, sehingga pada beberapa jenis PJB yang berat mungkin telah meninggal sebelum terdeteksi ${ }^{7}$.

Berdasarkan hal diatas, perlu diteliti profil penyakit jantung bawaan di IKA RSUP Dr. M. Djamil Padang tahun 2013 -2015.

\section{METODE}

Jenis penelitian ini menggunakan metode deskriptif dengan desain studi potong lintang dengan pengambilan data rekam medis pasien rawat inap penyakit jantung bawaan di RSUP Dr.M.Djamil Padang periode 2013-2015.

Populasi penelitian adalah data rekam medik pasien rawat inap penyakit jantung bawaan di IKA RSUP Dr. M. Djamil Padang dari tanggal 1 Januari 2013 sampai dengan 31 Desember 2015. Sampel pada penelitian ini menggunakan teknik total sampling yaitu seluruh data populasi yang memenuhi kriteria yaitu pasien PJB rawat inap di RSUP M. Djamil Padang yang memiliki rekam medis. Data yang diambil merupakan data terakhir kontrol pasien. 
Selanjutnya, data diolah dan disajikan dalam bentuk tabel dan grafik. Data diolah dengan menggunakan komputer dan ditampilkan menggunakan tabel dan grafik.

\section{HASIL}

Pada periode Januari 2013 sampai Desember 2015 terdapat 85 pasien penyakit jantung bawaan di intalasi rawat inap IKA RSUP Dr. M. Djamil Padang. Berikut ini merupakan profil subjek penelitian sebanyak 85 kasus yang dijabarkan dalam bentuk tabel berdasarkan jenis PJB, usia, jenis kelamin, status gizi, penyakit penyerta, riwayat keluarga serta nilai hemoglobin dan hematokrit di instalasi rawat inap IKA RSUP Dr. M. Djamil Padang periode Januari 2013 sampai Desember 2015

Mayoritas pasien PJB yang dirawat adalah lakilaki $(54,12 \%)$ dengan status gizi terbanyak adalah gizi kurang $(63,53 \%)$, distribusi umur $>1$ tahun sebagai pasien terbanyak $(50,59 \%)$, dan jenis PJB sianotik merupakan jenis PJB terbanyak (49,42\%) dibandingkan PJB asianotik serta hanya dua kasus $(2,35 \%)$ yang memiliki riwayat keluarga (Tabel 1$)$.

Tabel 1. Karakteristik pasien penyakit jantung bawaan

\begin{tabular}{|c|c|c|}
\hline Karakteristik & $\mathbf{n}$ & $\%$ \\
\hline \multicolumn{3}{|l|}{ Jenis Kelamin } \\
\hline Laki-laki & 46 & 54,12 \\
\hline Perempuan & 39 & 45,88 \\
\hline \multicolumn{3}{|l|}{ Status Gizi } \\
\hline Obesitas & 0 & 0,00 \\
\hline Overweight & 0 & 0,00 \\
\hline Baik & 19 & 22,35 \\
\hline Kurang & 54 & 63,53 \\
\hline Buruk & 12 & 14,12 \\
\hline \multicolumn{3}{|l|}{ Umur } \\
\hline 0 - 28 hari & 7 & 8,23 \\
\hline - 1tahun & 35 & 41,18 \\
\hline$>1$ tahun & 43 & 50,59 \\
\hline \multicolumn{3}{|l|}{ Jenis PJB } \\
\hline Asianotik & 27 & 31,76 \\
\hline Sianotik & 42 & 49,42 \\
\hline Kombinasi & 16 & 18,82 \\
\hline \multicolumn{3}{|l|}{ Riwayat Keluarga } \\
\hline Ada & 2 & 2,35 \\
\hline Tidak Ada & 70 & 82,36 \\
\hline Tidak Diketahui & 13 & 15,29 \\
\hline Total & 85 & 100 \\
\hline
\end{tabular}

Jenis PJB terbanyak yang didapatkan adalah VSD $(40,00 \%)$, ToF $(38,82 \%)$, dan PDA $(31,76 \%)$, ASD $(18,82 \%)$ dan ToF $(38,82 \%)$. Kasus lain diantaranya adalah PS, PFO, AT dan beberapa lainnya (Tabel 2).

Tabel 2. Distribusi jenis PJB pada pasien rawat inap

\begin{tabular}{lll}
\hline Jenis PJB & $\mathbf{n}$ & $\mathbf{\%}$ \\
\hline VSD & 34 & 40,00 \\
ASD & 16 & 18,82 \\
PDA & 27 & 31,76 \\
ToF & 33 & 38,82 \\
TGA & 9 & 10,58 \\
Lain-lain & 16 & 18,82 \\
PS & 4 & 4,70 \\
PFO & 2 & 2,35 \\
AT & 2 & 2,35 \\
DORV & 2 & 2,35 \\
AP & 3 & 3,52 \\
AVSD & 1 & 1,17 \\
TAP & 1 & 1,17 \\
EA & 1 & 1,17 \\
\hline
\end{tabular}

Berdasarkan penyakit penyerta pada Tabel 3, sebagian besar pasien menderita kelainan paru $(42,35 \%)$ terutama pneumonia $(35,29 \%)$, dilanjutkan dengan penyakit infeksi (25,88\%) dan metabolik endokrin (18,82\%). Dari keseluruhan pasien sebagian menderita sindrom $(14,12 \%)$ terutama sindrom down $(10,59 \%)$.

Tabel 3. Distribusi berdasarkan penyakit penyerta

\begin{tabular}{lll}
\hline Penyakit Penyerta & Jumlah & $\%$ \\
\hline Kelainan Paru & 30 & 35,29 \\
Pneumonia & 1 & 1,17 \\
Pleuritis & 2 & 2,35 \\
- Bronkiolitis & 1 & 1,17 \\
- Pneumothorax & 2 & 2,35 \\
Efusi Pleura & & \\
Sindrom & 9 & 10,59 \\
Sindroma Down & 1 & 1,17 \\
Sindroma Cri du Chat & 2 & 2,35 \\
Sindroma Edward & 22 & 25,88 \\
Infeksi & 16 & 18,82 \\
Metabolik Endokrin & 3 & 3,53 \\
Renal & 7 & 8,24 \\
Neuro & 23 & 27,06 \\
Dan Lain-lain & 20 & 23,53 \\
Tanpa Penyakit Penyerta & & \\
\hline
\end{tabular}


Pada kasus PJB juga perlu diperhatikan parameter hematologis diantaranya hemoglobin dan hematokrit. Nilai hemoglobin rata-rata pasien PJB sianotik lebih besar daripada nilai hemoglobin rata-rata pasien PJB asianotik. Hal ini serupa dengan nilai hematokrit. Pada pasien PJB sianotik, nilai hematokritnya lebih tinggi dibandingkan nilai hematokrit pada pasien PJB asianotik (Tabel 4).

Tabel 4. Nilai rerata hemoglobin dan hematokrit pasien PJB

\begin{tabular}{lllll}
\hline Parameter & $\begin{array}{l}\text { Nilai } \\
\text { PJB Asianotik }\end{array}$ & $\begin{array}{l}\text { RJB Sianotik } \\
\text { PJB }\end{array}$ \\
& & & & $\begin{array}{l}\text { Rerata } \\
\text { Kombinasi }\end{array}$ \\
\hline Hemoglobin & $11,70 \mathrm{gr} / \mathrm{dL}$ & $14,37 \mathrm{gr} / \mathrm{dL}$ & $13,91 \mathrm{gr} / \mathrm{dL}$ \\
& $(\mathrm{SD} \pm$ & $\begin{array}{l}\text { Rerata } \\
\text { Hematokrit }\end{array}$ & $(\mathrm{SD} \pm 4,38$ & $(\mathrm{SD} \pm 2,54$ \\
& $\mathrm{gr} / \mathrm{dL})$ & $\mathrm{gr} / \mathrm{dL})$ & $\mathrm{gr} / \mathrm{dL})$ \\
& $33,78 \%$ & $46,51 \%$ & $44,31 \%$ \\
& $(\mathrm{SD} \pm 7,60 \%)$ & $(\mathrm{SD} \pm 13,91$ & $(\mathrm{SD} \pm 8,85$ \\
& & $\%)$ & $\%)$ \\
\hline
\end{tabular}

\section{PEMBAHASAN}

Kasus PJB paling banyak terjadi pada jenis ventricular septal defect (VSD), yaitu sebanyak 34 pasien (40,00\%). Pada buku IImu Kesehatan Anak Fakultas Kedokteran Universitas Indoensia (2007) juga mengatakan bahwa umumnya PJB terbanyak yaitu defek septum ventrikel (VSD), kemudian menyusul VSD+PS (stenosis pulmonal), ASD (defek septum atrium), PDA (duktus arteriosus persisten), koarktasio aorta, PS (stenosis pulmonal), AS (stenosis aorta), TGA (transposisi arteri-arteri besar), ToF (tetralogy of Fallot) ${ }^{8}$. Hal ini sejalan dengan data yang diperoleh dari Center for Disease Control and Prevention (CDC) bahwa prevalensi PJB tertinggi pada jenis VSD ${ }^{9}$. Berdasarkan penelitian di Georgia, prevalensi pasien ventricular septal defect (VSD) pada tahun 1968-1997 didapatkan sebanyak 1559 kasus $(26,8 \%)$ dari 5813 kasus. Angka ini merupakan angka kejadian tertinggi dibandingkan dengan jenis PJB lainnya ${ }^{10}$.

Frekuensi relatif PJB menunjukkan 3 PJB terbanyak ditempati oleh VSD, ToF dan PDA berturutturut $40 \%, 39 \%$ dan $32 \%$. Hal ini tidak jauh berbeda dengan hasil penelitian Liu et al (2015) yang dalam penelitiannya dilaporkan bahwa VSD, ASD dan PDA merupakan lesi terbanyak yaitu $29 \%, 21 \%$ dan $14 \%{ }^{11}$. Namun penyebab pasti mengapa VSD merupakan jenis PJB terbanyak masih belum diketahui. Hal ini terkait dengan kekurangan dalam penelitian ini yang tidak meneliti tentang faktor risiko PJB.

Dalam penelitian ini, kasus PJB lebih banyak terjadi pada kelompok umur kategori batita ( $>1$ tahun) yaitu sebanyak 43 kasus (50,59\%). Hasil ini tidak jauh berbeda dengan penelitian yang dilakukan oleh Nur Ain (2015) yang juga menunjukkan bahwa anak penderita PJB lebih banyak ditemukan pada kelompok umur $>1$ tahun kehidupan yaitu sebanyak 24 kasus $(43,60 \%)^{12}$. Pada penelitian di Manado juga didapatkan bahwa penderita PJB terbanyak dalam kurun 4 tahun yaitu pada kelompok umur 1-6 tahun ${ }^{13}$. Pada penelitian Shah (2008) yang dilakukan terhadap 84 pasien PJB didapatkan kelompok terbanyak pada usia 29 hari-1 tahun ${ }^{14}$. Ada dugaan bahwa hal ini dipengaruhi oleh penurunan rerata umur bayi terdiagnosis PJB akibat kelemahan dari penelitian atau keterlambatan pasien datang ke rumah sakit ${ }^{10}$.

Kasus PJB lebih banyak terjadi pada laki-laki dibandingkan perempuan, yaitu sebanyak 46 pasien $(54,12 \%)$. Hal yang sama juga dibuktikan oleh Maramis et al (2014), pada penelitian yang dilakukan di RSUP. Prof. Dr. R. D. Kandou Manado tahun 20092013 didapatkan dari 53 anak penderita penyakit jantung bawaan didapatkan 34 anak berjenis kelamin laki-laki dan 19 anak berjenis kelamin perempuan ${ }^{13}$. Penelitian yang sama juga pernah diteliti di India, dengan hasil kasus PJB banyak terjadi pada laki-laki dengan presentase $67,07 \%{ }^{15}$. Berdasarkan penelitian Nikyar et al (2011) terhadap 97 pasien di Dezyani hospital, Iran menyatakan bahwa pasien PJB terbanyak pada laki-laki daripada perempuan dengan perbandingan 9,96 dengan 7,34 per 1000 kasus $^{16}$.

Berdasarkan penelitian, status gizi pasien PJB lebih banyak dengan kondisi gizi kurang yaitu sebanyak 64 kasus (75,30\%). Sedangkan pada penelitian ini, tidak ditemukan adanya pasien PJB dengan gizi lebih. Pasien PJB memiliki frekuensi yang tinggi terhadap kelainan kongenital yang multiple, syndrome, berat badan lahir rendah (yang menjadi risiko malnutrisi kedepannya) dan keterlambatan 
pertumbuhan ${ }^{17}$. Kelainan jantung bawaan yang diserta peningkatan aliran darah ke paru yang hebat, hipoksemia berat atau gagal jantung kongestif kronis dapat mengakibatkan hambatan pertumbahan dan perkembangan jasmani, motorik dan mental penderita $^{8}$. Sejalan dengan penelitian Shrivastava (2008) yang mengatakan bahwa pasien dengan aliran darah ke paru yang bertambah dan hipertensi pulmonal akan lebih banyak mengalami malnutrisi dan gangguan pertumbuhan yang berhubungan dengan hipoksia pada pasien PJB sianotik ${ }^{18}$. Jika dilihat menurut pertumbuhan anak, pasien dengan kelainan jantung ringan mengalami keterlambatan pertumbuhan ataupun kegagalan dalam peningkatan berat badan ${ }^{19}$. Anoreksia, asupan nutrisi yang tidak adekuat, hipoksemia jaringan, status hipermetabolik, asidemia, dan ketidakseimbangan kation, aliran darah perifer yang berkurang, dekompensasi jantung kronis, malabsorbsi maupun kehilangan protein, infeksi saluran pernafasan berulang, faktor hormonal dan genetik akhirnya akan menyebabkan malnutrisi ${ }^{6}$.

Pneumonia menempati urutan pertama penyakit penyerta pada pasien PJB di rawat inap IKA RSUP Dr. M. Djamil Padang periode Januari 2013 Desember 2015. Penderita kelainan jantung bawaan yang disertai peningkatan aliran darah ke paru yang bermakna seringkali menderita infeksi saluran nafas bagian atas maupun pneumonia berulang. Infeksi dapat disebabkan oleh virus, bakteri maupun mikroorganisme lain. Hal ini disebabkan antara lain oleh karena traktus respiratorius penderita menjadi 'basah' sehingga fungsi toilet bronkial menjadi terganggu ${ }^{8}$. Jika dilihat dari penelitian Owayed et al (2000), PJB merupakan salah satu faktor risiko terjadinya pneumonia berulang pada $a^{2} \mathrm{k}^{20}$. Sindrom terbanyak yang menyertai PJB yaitu sindroma down sebanyak 9 kasus (10,59\%). Hal ini sesuai dengan penelitian Ain (2015), bahwa kelainan berupa sindroma terbanyak adalah sindroma down yaitu sebanyak 40\%. Risiko untuk mendapatkan anak dengan kondisi ini meningkat dengan pertambahan usia maternal, terutama di atas usia 35 tahun. Anak dengan sindroma Down menderita mental retardasi dari ringan sampai sedang, dan masalah kesehatan yang bervariasi termasuk $\mathrm{PJB}^{12}$.

Pada penelitian ini, pasien PJB yang memiliki riwayat keluarga hanya 2 orang (2,35\%). Secara umum, saat seorang anak menderita PJB, berisiko terjadi rekurensi sebesar $3 \%{ }^{19}$. Dan juga riwayat keluarga ini tidak konklusif, tetapi data statistik menunjukkan bahwa beberapa kelainan jantung bawaan serta penyakit jantung didapat (reuma) mempunyai kecendrungan familiar. Faktor genetic memegang peranan kecil saja, sedangkan kelainan kromosom biasanya tidak terdapat. Walaupun demikian beberapa keluarga mempunyai insidens PJB tinggi, jenis PJB yang sama terdapat pada anggota keluarga yang sama ${ }^{8}$.

Untuk parameter hematologis, nilai hemoglobin dan hematokrit pada penelitian ini sangat bervariasi. Nilai hemoglobin rata-rata pada pasien PJB asianotik yaitu $11,97 \mathrm{gr} / \mathrm{dL}$ dan nilai hematokrit rata-rata pasien PJB asianotik yaitu 42,7\%. Sedangkan nilai hemoglobin rata-rata pada pasien PJB sianotik yaitu 14,87 gr/dL dan nilai hematokrit rata-rata pasien PJB sianotik yaitu $48,6 \%$. Serta nilai hemoglobin rata-rata pada pasien PJB kombinasi yaitu $14,39 \mathrm{gr} / \mathrm{dL}$ dan nilai hematokrit rata-rata pasien PJB kombinasi yaitu 45,9\%. Hal ini sesuai dengan penelitian Ain (2015), bahwa dari keseluruhan pasien PJB, didapatkan nilai $\mathrm{Hb}$ rata-rata yaitu $13,7 \mathrm{gr} / \mathrm{dL}^{12}$. Jika dibedakan nilai rata-rata $\mathrm{Hb}$ dan $\mathrm{Ht}$ antara $\mathrm{PJB}$ sianotik dengan asianotik, didapat bahwa nilai $\mathrm{Hb}$ dan $\mathrm{Ht}$ pada penderita PJB sianotik lebih tinggi. Parameter hematologis ini memengaruhi prognosis pasien sehingga penting untuk diteliti.

Pada penderita PJB sianotik, terjadi eritrositosis sekunder yang merupakan respon fisiologis akibat hipoksemia kronik jaringan, yang akan merangsang eritropoesis di sumsum tulang. Kadar oksigen arterial yang rendah akan menstimulasi sumsum tulang melalui pelepasan eritropoietin di ginjal yang akan meningkatkan produksi sel darah merah sehingga terjadi peningkatan massa sel darah merah, hematokrit dan viskositas darah. Peningkatan sel darah merah yang bersirkulasi merupakan respon 
kompensasi untuk meningkatkan transport oksigen ke jaringan agar suplai oksigen ke jaringan adekuat. Namun peningkatan viskositas serum ini malah akan mengurangi kecepatan aliran darah dan perfusi ke jaringan serta gangguan penghantaran oksigen ke jaringan $^{12}$

\section{SIMPULAN}

Jenis penyakit jantung bawaan terbanyak ditemui adalah ventricular septal defect (VSD), selanjutnya tetralogy of fallot (ToF) dan patent ductus arteriosus (PDA).

Kelompok usia terbanyak pasien penyakit jantung bawaan adalah kelompok usia $>1$ tahun.

Penyakit jantung bawaan lebih sering terjadi pada laki-laki.

Pasien penyakit jantung bawaan sebagian besar memiliki gizi kurang.

Penyakit penyerta yang diderita pasien penyakit jantung bawaan terbanyak yaitu kelainan paru dengan jenis terbanyak yaitu pneumonia.

Sebagian besar pasien penyakit jantung bawaan tidak memiliki riwayat keluarga

Nilai hemoglobin dan hematokrit pada pasien penyakit jantung bawaan sangat bervariasi. Tampak perbedan nilai parameter hematologis pada PJB sianotik dan asianotik dengan hasil PJB sianotik memiliki nilai hemoglobin dan hematokrit lebih tinggi

\section{DAFTAR PUSTAKA}

1. Primasari D. Perbedaan Perkembangan Pada Anak Dengan Penyakit Jantung Bawaan Sianotik Dan Non Sianotik. Semarang: Fakultas Kedokteran Universitas Diponegoro. 2012.

2. Djer MM, Madiyono B. Tatalaksana penyakit jantung bawaan. Sari Pediatri. 200;2(3):155-62.

3. Hoffman IJ, Kaplan S. The incidence of congenital heart disease American collage of cardiology. 2002:39(12):1890-900.

4. Aripriandari A. Perbedaan pengetahuan tentang penyakit jantung bawaan antara orangtua pasien di pusat pelayanan kesehatan primer dan tersier. Semarang: Fakultas Kedokteran Universitas Diponegoro. 2011.
5. Windarini P. Karakteristik penderita penyakit jantung bawaan pada anak tahun 20017-2009 di RSUP H. Adam Malik Medan. Medan: Fakultas Kedokteran Universitas Sumatera Utara; 2010.

6. Hariyanto D. Profil penyakit jantung bawaan di instalasi rawat inap anak RSUP Dr. M. Djamil Padang Januari 2008-Februari 2011. Sari Pediatri. 2012:14(3):152-7.

7. Roebiono PS. Diagnosis dan tatalaksana penyakit jantung bawaan. 2003 (diunduh 8 Februari 2016). Tersedia dari: http://staff.ui.ac.id/system/files/ users/poppy.roebiono/material/diagnosisdantatalak sanapjb-2.pdf.

8. Hasan $\mathrm{R}$, Alatas $\mathrm{H}$. Buku kuliah ilmu kesehatan anak. Jakarta: Bagian IImu Kesehatan Anak Fakultas Kedokteran Universitas Indonesia; 1991.

9. Center for Disease Control and Prevention (2016). Heart Defect. 2016 (diunduh 2 Desember 2016). Tersedia dari: http://www.cdc.gov/ncbddd/ heartdefects/data.html.

10. Botto LD, Correa A, Erickson JD. Racial and temporal variations in the prevalence of heart defects. Pediatrics. 2001;107(3).

11. Liu F, Yang Y, Xie X, Li X, Ma X, Fu Z. Prevalence of congenital heart disease in Xinjiang multi-ethnic region of China. Plos One. 2015;10(8).

12. Ain N. Karakteristik penderita penyakit jantung bawaan pada anak di RSUP Dr. M. Djamil Padang periode Januari 2010 - Mei 2012. Jurnal Kesehatan Andalas. 2015;4(3):928-35.

13. Maramis PP, Kaunang ED, Rompis J. Hubungan penyakit jantung bawaan dengan status gizi pada anak di RSUP Prof. Dr. R. D. Kandou Manado Tahun 2009-2013. Jurnal e-Clinic. 2014;2(2).

14. Shah G, Singh M, Pandey T, Kalakheti B, Bhandari G. Incidence of congenital heart disease in tertiary care hospital. Kathmandu University Medical Journal. 2008: 33-6.

15. Begum R, Pathak K, Das H. Incidence and pattern of congenital heart disease in children - a hospital based study. IOSR Journal of Dental and Medical Sciences. 2016:08-11.

16. Nikyar B, Sedehi M, Mirfazeli A, Qorbani M, \& Golalipour M. Prevalence and pattern of congenital 
heart disease among neonates in Gorgan, Northern Iran (2007-2008). Iran J Pediatr. 2011; 307-12.

17. Gomella TL. Neonatology. Maryland: Mc Graw Hill. 2014.

18. Shrivastava $S$. Malnutrition in congenital heart disease. Indian Pediatrics. 2008:535-6.
19. Park MK. Park's pediatric cardiology for practitioners. Philadelphia: Elsevier: 2014.

20. Owayed AF, Campbell DM, Wang EE (2000). Underlying causes of recurrent pneumonia in children. Arch Pediatr Adolesc Med. 2000:190-4. 